\title{
DGKH wt Allele
}

National Cancer Institute

\section{Source}

National Cancer Institute. DGKH wt Allele. NCI Thesaurus. Code C119659.

Human DGKH wild-type allele is located in the vicinity of $13 q 14.11$ and is approximately

$217 \mathrm{~kb}$ in length. This allele, which encodes diacylglycerol kinase eta protein, is involved in second messenger signaling to promote cell growth. 